\title{
BONE DEFECT REGENERATION WITH BIOACTIVE GLASS IMPLANTATION IN RATS
}

\author{
REGENERAÇÃO DE DEFEITOS ÓSSEOS COM VIDRO BIOATIVO IMPLANTADO EM RATOS
}

Nelson Luiz de MACEDO ${ }^{1}$, Fábio da Silva MATUDA² ${ }^{2}$ Luís Guilherme Scavonne de MACEDO ${ }^{3}$, Michel Borges GONZALEZ ${ }^{3}$, Suzana Martins OUCHI ${ }^{3}$, Yasmin Rodarte CARVALHO ${ }^{4}$

\begin{abstract}
1- Associate Professor, Department of Surgery, Periodontics and Radiology, São José dos Campos Dental School, UNESP - São José dos Campos, SP - Brazil.

2- Postgraduate student in Restorative Dentistry - São José dos Campos Dental School, UNESP - São José dos Campos, SP - Brazil.

3- Participant of the Continuing Education Program - São José dos Campos Dental School, UNESP - São José dos Campos, SP - Brazil.

4- Associate Professor, Department of Biosciences and Diagnosis - São José dos Campos Dental School, UNESP - São José dos Campos, SP - Brazil.

Corresponding address: Nelson Luiz de MACEDO - Department of Surgery, Periodontics and Radiology, São José dos Campos Dental School, UNESP - São José dos Campos, SP - Brazil. Av. Engenheiro Francisco José Longo, 777- Caixa Postal- 314- CEP 12201-970- São José dos Campos- SP. Phone: 0xx12 39479047 / 0xx12 97272368
\end{abstract}

Received: May 05, 2003 - Returned for modification: June 06, 2003 - Accepted: August 08, 2003

\begin{abstract} $T_{\text {he main goal of this study was to histologically evaluate the healing of surgically created defects on the tibiae of adult male }}$ rats after implantation of two types of bioactive glass. Sixteen adult Wistar rats (body weight of 300g) were divided into two groups: PerioGlas (PG) $(n=8)$ and BioGran $(B G)(n=8)$. Unicortical bone defects with 3-mm diameter were performed in both tibiae of the animals and filled with two types of glass particles. The rats were then sacrificed at 7, 14, 30 and 60 days, and the tissues were prepared for histological processing, sectioning, and staining with hematoxylin and eosin, as well as Mallory trichrome, and analyzed under light microscope. Within 7-14 days, both groups presented connective tissue septa with new bone formation, more intense in the PG group. In the subsequent periods (30 and 60 days), both groups presented more mature bone tissue around the glass particles. Bone trabeculae formed in all experimental periods were juxtaposed to the glass particles. It can be concluded that both materials promoted comparable bone formation over the entire extension of the defect, independently of the size of the granules, thus confirming their biological osteoconductive property.

UNITERMS: Bone regeneration; Bioactive ceramic; Bone repair; Implant; Bioactive glass.
\end{abstract}

\section{RESUMO}

$O$

objetivo deste estudo foi avaliar a resposta histológica após a implantação de dois tipos de cerâmicas bioativas em defeitos criados na tíbia de ratos. Dezesseis ratos da raça Wistar, pesando 300g, foram divididos em dois grupos: PerioGlass (PG) $(n=8)$ e Biogran (BG) (n=8). Defeitos ósseos unicorticais de $3 \mathrm{~mm}$ de diâmetro foram realizados na tíbia dos animais e preenchidos com os dois tipos de partículas cerâmicas. Os animais foram sacrificados aos 7, 14, 30 e 60 dias no pós-operatório. O material preparado para processamento e exame histológico em microscopia óptica foi corado com hematoxilina-eosina e tricrômio de Mallory. Aos 7 dias ambos os grupos apresentaram septos ósseos neoformados, mais intensos no grupo PG. Isto também foi observado aos 14 dias. Nos períodos posteriores (30 e 60 dias), ambos os grupos apresentaram tecido ósseo mais maduro ao redor das partículas cerâmicas. As trabéculas ósseas formadas em todos os períodos experimentais foram justapostas com as partículas. Podemos concluir que ambos os materiais promoveram o preenchimento ósseo em toda a extensão do defeito independente de suas granulações comprovando suas propriedades osteocondutivas.

UNITERMOS: Regeneração óssea; Cerâmica bioativa; Reparação óssea; Implante; Biogran.

\section{INTRODUCTION}

The autogenous material is still the best choice for reconstruction of bone defects (Boyne $^{2}, 1997$; Vasconcelos, et $a . .^{25}$, 1998). However, this type of graft involves additional surgical trauma to the patient and very often cannot be obtained in sufficient amount to fill the whole defect; moreover, not all patients will accept to undergo surgery for removal of donor material from the iliac crest, tibia or skull.

The interest in the development and use of a synthetic 
material has led to the development of several studies evaluating the results of the utilization of hydroxyapatite (HA) as a bone tissue substitute (Jarcho, et al. ${ }^{8}, 1986$; Mellonig, et al. ${ }^{14}$, 1991; Kenney, et al. ${ }^{11}$, 1985; Novaes Jr., et al. $\left.{ }^{16}, 1990\right)$. Clinical and histological studies have shown involvement of HA granules with the connective tissue, with no incorporation in the neighboring bone tissue, in addition to a more prominent inflammatory response with this type of alloplastic material (Salata, et al. ${ }^{20}$, 1998). The treatment of localized atrophies of the alveolar ridge with masticatory membrane autogenous grafting and hydroxyapatite implants presents some drawbacks and technical problems (Seibert, Nyman²2, 1990).

The use of allogenic materials has been discussed due to the possibility of disease transmission, small amount of bone morphogenetic protein, and also due to non-vital bone particles remaining inside the repaired defect (Becker, et al. ${ }^{1}$; 1994; Low, et al.12 1997). Results obtained in studies using biomaterials have presented controversial data, which due to a lack of information may lead professionals to use materials that do not produce the expected advantages after treatment of several kinds of bone defects.

Application of the biological principles of guided bone regeneration has rendered interesting results in minor osseous defects (Macedo, et al. ${ }^{13}$, 1993; Buser, et al. ${ }^{3}$, 1995; Jovanovic, et al. ${ }^{9}$, 1995). Nevertheless, membrane exposition can occur and its consequent contamination may produce local infection, thus hindering the desired new bone formation.

Unexpected results due to the use of the materials and techniques mentioned above have directed technological advances to recent studies with some bio-active materials to be used as bone substitutes, in several kinds of defects in the field of Dentistry. Bioactive glass has shown the ability to help bone regeneration and clinical insertion gain, with better results than other materials available (Wilson, Low ${ }^{27}$, 1992; Low, et al. ${ }^{12}$, 1997; Turunen, et al. ${ }^{24}$, 1997; Zamet, et al. ${ }^{30}$, 1997; Shapoff, et al. ${ }^{23}$, 1997).

This material has also demonstrated osteoconductive and osteopromotive abilities in the biocompatible interface for osseous migration, and a bioactive surface colonized by osteogenic cells free in the surgical wound (Schepers, et al. ${ }^{21}$, 1991, Wilson, Low $^{27}$, 1992). Their ability to bond to soft and osseous tissues seems to make a difference when compared to other alloplastic materials available (Wilson, et al. ${ }^{26}$, 1993, Hench, et al. ${ }^{6}, 1973$, Hench, et al. ${ }^{7}$ 1971). Zamet, et al. ${ }^{30}, 1997$, have evaluated the effects of a bioactive glass (PerioGlas) in the treatment of intrabony periodontal defects with a higher reduction of probing depth when compared to conventional treatments.

Such findings are in agreement with those of Low, et al. ${ }^{12}, 1997$, who demonstrated clinical attachment gain and probing depth reduction after implantation of this bioactive glass in bone defects. The use of BioGlass particles promotes a much faster proliferation of new bone tissue, comparable to that occurring after the use of autogenous bone graft; furthermore, the combination of BioGlass granules and autogenous bone results in more bone growth when compared to the autogenous material (Oonishi, et al. ${ }^{17}, 1997$ ).

Based on these facts, this comparative experimental study has histologically evaluated the bone tissue response, and its regenerative potential in the healing of bone defects created in rat tibiae following implantation of two types of bioactive glass particles.

\section{MATERIALAND METHODS}

In the present study, 16 male rats (Rattus norvegicus, albinus, Wistar) weighing $300 \mathrm{~g}$ were used, which were fed a solid diet before and during the experimental period (Moinho Primor SA, Brazil) and received water ad libitum. The entire experimental study was carried out according to the Ethics Principles on Animal Experiments of São José dos Campos Dental School, UNESP.

\section{Bone Substitutes}

Two kinds of synthetic resorbable materials, in the form of granules - PerioGlas (US Biomaterials Corporation, Alachua, Florida, USA) and Biogran (Orthovita, Malvern, $P A, U S A$ ) were used for treatment of the bone defects. Both bioactive glass materials present the same chemical composition - 45\% silicon dioxide $\left(\mathrm{SiO}_{2}\right), 24.5 \%$ calcium oxide (CaO), $24.5 \%$ sodium oxide $\left(\mathrm{NaO}_{2}\right)$, and $6 \%$ phosphorus pentoxide $\left(\mathrm{P}_{2} \mathrm{O}_{5}\right)$ - differing only in the diameter of the granules. Biogran presents more regular granules - 300 to 355ìm, whereas Perioglas has more irregular granules, ranging from 90 to 710ìm. Eight animals were employed for each material.

\section{Surgical Procedure}

Before surgery, the animals were weighed for a correct calculation of the anesthetic dosage. General anesthesia was used with intramuscular application of a sedative solution - hydrochloride 2-(2.6 xylidine)-5.6-dyhidro-4H-1.3thiazine (Rompum, Bayer do Brasil), and ketamine anesthetic 1.0g (Francotar, Virbaxil, Virbac do Brasil Indústria e Comércio Ltda., São Paulo, Brazil), in the proportion of $1: 0.5 \mathrm{ml}$ in the $0.1 \mathrm{ml} / 100 \mathrm{~g}$ of body weight.

After trichotomy and asepsis of the surgical field with iodine, the lateral and superior aspects of the tibiae in both posterior paws were exposed with a 1.5-cm long incision, using a \#15 interchangeable blade, on a Bard-Parker scalpel.

Tissue separation was performed with periosteum elevators and a Molt elevator, so as to obtain a mucoperiosteal flap to expose the bone tissue and allow free access to create osseous defects. In both paws, a monocortical bone defect measuring $3 \mathrm{~mm}$ in diameter was prepared with Asseptico electric engine (AEU-707-MGF Asseptico Inc., USA), using a 1/16 reduction, straight tip, trephine drills, at a speed of 1500rpm, under copious irrigation with $0.9 \%$ sterile saline solution throughout the bone manipulation. Before placing bone filling glass materials, the bone cavities were irrigated with antibiotic (Rifocina M, 
Lepetit SA, São Paulo, Brazil), in the proportion of $75 \mathrm{mg} /$ $20 \mathrm{ml}$ sterile saline.

On the right posterior paw, PerioGlas (PG) granules were placed to fill the defect; on the left paw, the defect was filled with BioGran (BG) granules, carefully in order to avoid excessive filling. Both materials were prepared just before being used, $0.9 \%$ sterile saline solution was added to the flasks, sterilized with gamma rays provided by the manufacturer, until a paste-like texture was obtained.

The flaps were closed with 4-0 silk intermittent sutures (Ethicon, Jonhson \& Johnson) and deeper planes were closed with absorbable Vicryl 4-0 suture (Ethicon, Johnson \& Johnson).

Immediately after the surgical procedure, all animals received intramuscular application of antibiotics and antiinflammatory (Agrovet Plus, Ciba-Geigy Química, SA, São Paulo, Brazil), in the dosage of $0.2 \mathrm{ml} / \mathrm{kg}$ of body weight.

\section{Histological Study}

The animals were sacrificed with an overdose of anesthetic at 7, 14, 30 and 60 days after the surgical procedures. After removal of soft tissues, bone fragments including the implanted material were obtained and fixed in a $10 \%$ formalin solution for at least 48 hours. Decalcification was accomplished in 20\% sodium citrate and 50\% formic acid solution, 1:1. Tthe decalcified samples were embedded in paraffin and 6 - $\mu \mathrm{m}$ thick semi-serial sections were obtained and stained with hematoxylin-eosin and Mallory trichrome for light microscopy analysis.

\section{RESULTS}

After seven days, the spaces filled by particles of implanted materials showed varying sizes and were surrounded by granulation tissue and thin woven bone trabeculae. Some of the trabeculae were lamellar and were associated with marrow tissue. That aspect could be seen up to the center of the surgical defect, extending inside the marrow space. Some particle spaces were divided by thin bone septa on the inside, dividing them into smaller portions. New bone formation was observed next to the defect borders, with newly formed trabeculae covered by osteoblasts, both facing the periosteum and inside the medullar channel (Figures 1 and 2).

After 14 days, bone trabeculae surrounding the spaces taken up by implanted particles were more mature and interspersed with bone marrow. On the surgical defect margins, basophilic lines could be observed inside the bone tissue, which indicates a remodeling process. Mild signs of excavated internal pouches of granules could be seen, which would function as sites to stimulate new bone formation (Figure 3).

After 30 days, bone trabeculae surrounding the spaces of the particles were thicker and more mature than in the previous stages, which showed signs of remodeling, as occurred on the surgical defect borders, and were interspersed with bone marrow. In some spaces, bone tissue formed in their excavations was observed in addition to thin bone septa. Other spaces presented delicate fibrilar material, sometimes with a reticular aspect (Figures 4 and 5).

After 60 days, bone trabeculae surrounding the spaces taken up by particles were thicker, with a lamellar aspect, and were interspersed with bone marrow. Inside some of the spaces, a remaining structure from the implanted material was found integrated to the bone tissue, besides thin bone septa. These spaces showed a material with delicate fibrilar aspect, occasionally with a reticular appearance. There was bone growth inside granules in both materials, with indications of bone remodeling (Figures 6, 7, and 8).

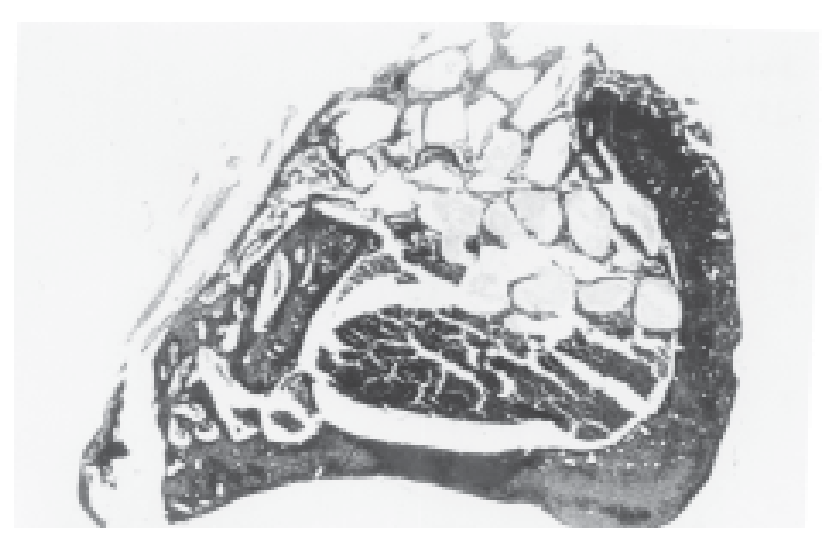

FIGURE 1- Biogran (BG) 7 days. Spaces taken up by glass particles of varying sizes $(A)$; thin bone trabeculae, some of them with lamellar aspect and marrow tissue. Some spaces are subdivided by thin bone septa, new bone formation next to defect margins (B), facing the periosteum and the inner part of the marrow space. Mallory trichrome. Magnification 25x

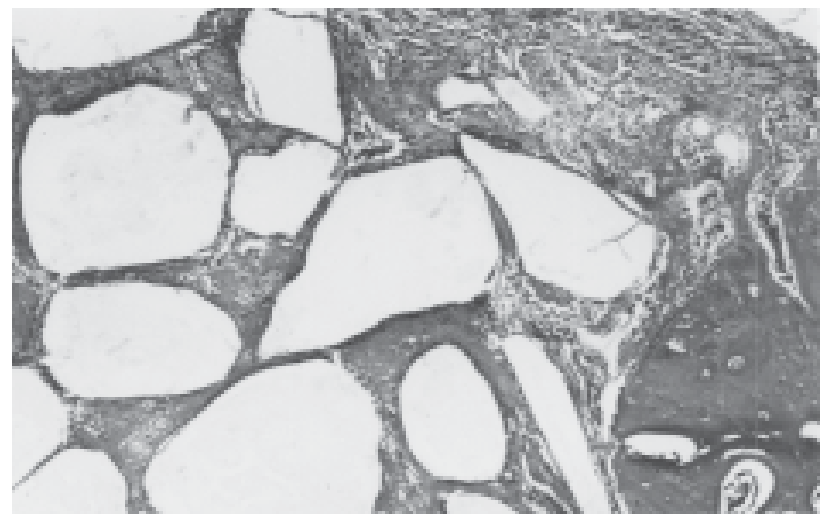

FIGURE 2- Perioglass (PG) 7 days. Spaces filled with glass particles of varying sizes, encircling granulation tissue; immature bone trabeculae $(A)$; scarce mononuclear inflammatory infiltrate. There are newly formed bone trabeculae next to the defect margins, surrounded by osteoblasts. Sub-periosteal new bone formation, next to the defect (B). HE. Magnification 100x 


\section{DISCUSSION}

The main goal when treating bone defects is regeneration of the bone tissue destroyed by diseases, traumas, etc. Frequently, guided bone regeneration techniques have been used as well as autogenous, xenogenic and allogenic bone grafts, and alloplastic materials that ideally would have good osteoinductive potential, which causes minimal inflammatory reactions, rapid vascularization, affinity with host tissues, easy accessibility, and should be inexpensive (Park, et al. ${ }^{18}$, 2001).

Although autogenous bone grafts are considered the best and most widely accepted material for treatment of bone defects, it requires an additional surgery on the donor area, and many times it cannot be found in sufficient amounts for complete filling of the lesion, thus leading to the search for substitute materials. The allogenic bone can cause a sustained inflammatory response; furthermore, there is a possibility of disease transmission.

Certain glass materials, such as tricalcium phosphate, hydroxyapatite, and calcium carbonate, have been used. Tricalcium phosphate presents low osteoinductivity and is rapidly reabsorbed. Some types of hydroxyapatite are encapsulated by the connective tissue and therefore they do not allow true bone tissue regeneration. Recently, clinical applications of bioactive glass in dentistry have become a common practice. On the initial implantation stage, they bond to the bone tissue, inhibiting fibroblastic growth. Materials tested in this study consisted of $45 \% \mathrm{SiO}_{2}, 24.5 \%$ $\mathrm{CaO}, 24.5 \% \mathrm{NaO}_{2}$, and $6 \% \mathrm{P}_{2} \mathrm{O}_{5}$, for maximum bone affinity and osseointegration. The particles pack into bone holes easily and stay in place, even when the surgical wound is bleeding.

According to the manufacturer, the particles of Biogran form a protective vesicle, as a central mushroom-type, starting with fissure formation acting as an osteogenesis nucleus, which confers osteoconductive properties. These particle fissures and pores allow optimum space for vascularization. This material is easy to handle and has hemostatic effect and high biocompatibility. Schepers, et

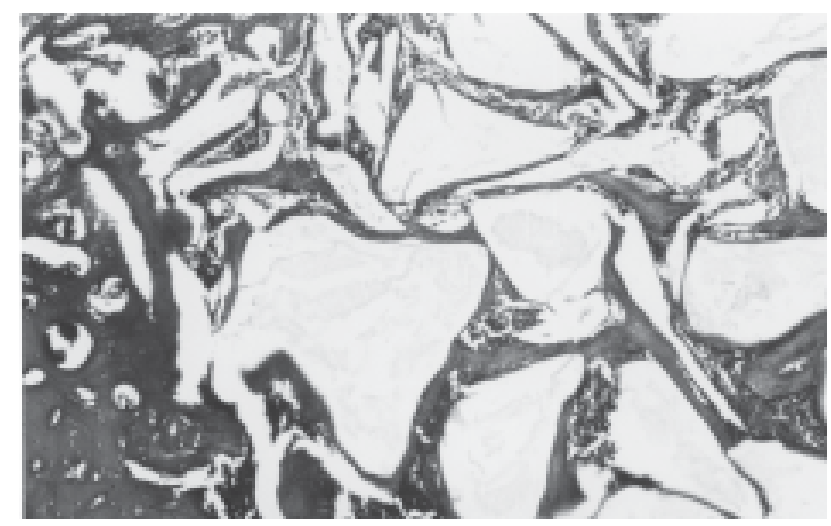

FIGURE 3- PG 14 days. Larger amount of bone tissue around the particle spaces, with mature aspect $(A)$; bone marrow between trabeculae; remodeling basophilic lines inside the bone tissue (B). HE. Magnification 100x al. ${ }^{21}$, 1991, studied the osteogenesis stimulated by bioactive glass and showed that the ionic exchange on the interface between particles and tissue fluids forms a silica gel layer which is rich in $\mathrm{Ca}$ and $\mathrm{P}$.

Cordioli, et al. ${ }^{4}$, 2001, used bioactive glass granules (Biogran) in combination with autogenous bone in surgeries for maxillary sinus elevation in patients with three to five millimeter bone height at the alveolar ridge, which showed a predictable surgical procedure with achievement of good quality and adequate bone volume. Our results histologically confirm that the bioactive glass particles showed osteoconductive and osseointegration properties, as

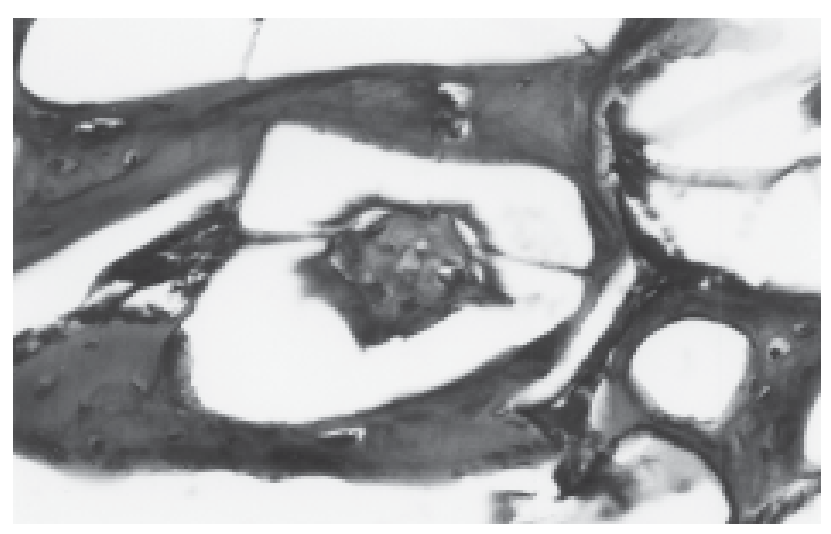

FIGURE 5 - PG 30 days. Spaces filled with particles surrounded by more mature bone tissue; indications of remodeling $(A)$. In some of the spaces, the presence of bone tissue $(B)$ can be observed (apparently formed inside them), as well as thin bone septa. Delicate fibrilar material inside other spaces, occasionally with reticular aspect. Bone trabeculae interspersed with bone marrow. Bone growth can be observed inside the granule. HE. Magnification 400x

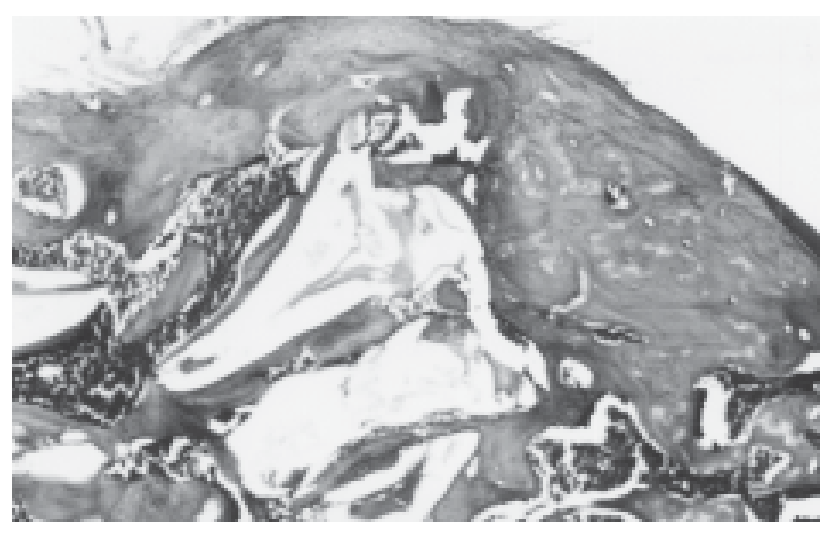

FIGURE 4 - BG 30 days. Bone trabeculae surrounding the spaces taken up by glass particles are thicker and more mature $(A)$, with indications of remodeling, as on defect margins, and interspersed with bone marrow. Thin bone septa are found inside the spaces (B). Fibrilar aspect has also been found in this group. HE. Magnification 100x 


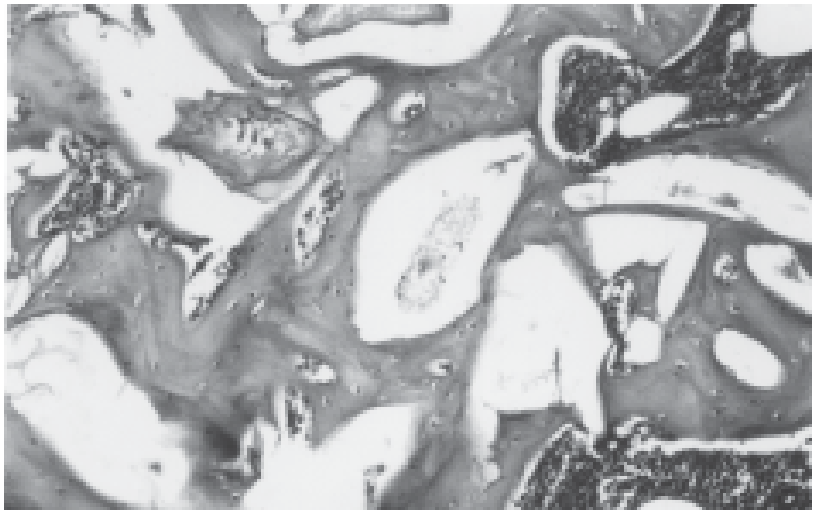

FIGURE 6 - PG, 60 days. Thicker lamellar bone trabeculae surrounding the spaces taken up by glass; interspersed with bone marrow $(A)$, with indications of bone remodeling. HE. Magnification 200x

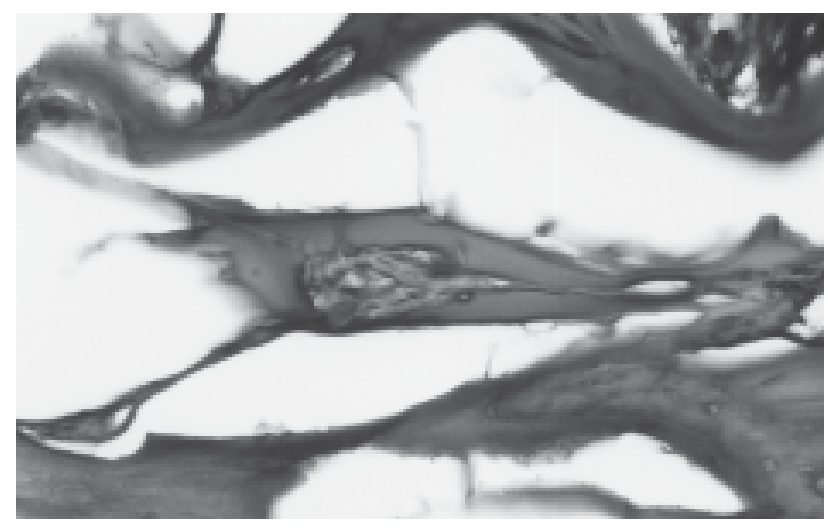

FIGURE 7 - BG, 60 days. Lamellar bone trabeculae surrounding the spaces filled with glass are thicker. Inside some spaces, a structure remaining from the implanted material (A) may be observed amidst the bone tissue, besides some thin bone septa. Bone growth can be observed inside the granule (B). HE. Magnification 400x

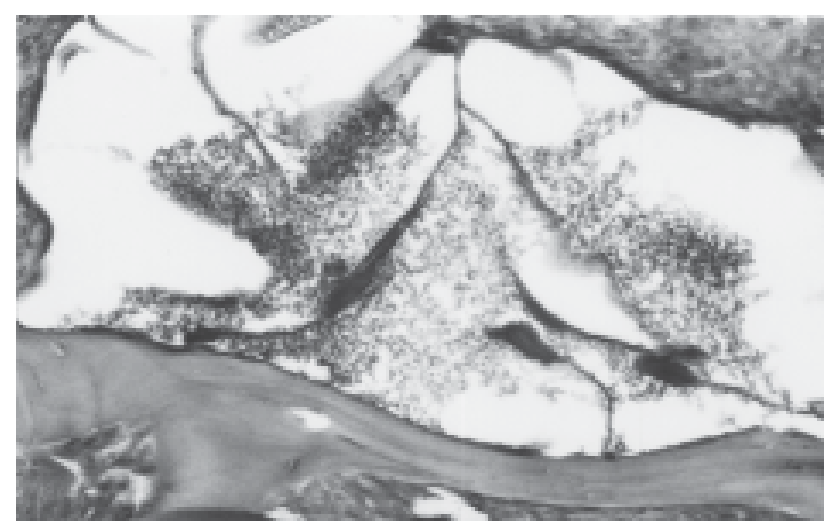

FIGURE 8 - BG, 60 days. Detail of granule excavation (A) showing newly formed bone (B) and reticular aspect of the material. HE. Magnification 400x documented by the close contact between the material and the newly formed bone, as well as bone growth around them and inside the granules. Both materials presented transformed particles and were smaller than the original, due to partial dissolution through ionic exchange with tissue fluids. At the final stage of evaluation, the histological material showed areas with osteoid tissue (bone tissue being formed), which would call for a longer time for bone maturation and complete resorption of the material with bone replacement.

According to Moore, et al. ${ }^{15}$, 2001, bioactive glass granules are more quickly reabsorbed than hydroxyapatite, thus allowing a much more precocious new bone formation in the repair of bone defects. On them, osteoblasts show several cytoplasmic processes, pseudopodia, compact appearance, and disorderly dorsal surface, which characterize a high cell membrane activity. Therefore, as to the adhesion and close contact between osteoblasts, bioactivity should be considered crucial to the development of new bases for bone tissue bioengineering. Its use in medical and dental areas, due to the excellent biocompatibility and its physical and chemical properties, has encouraged studies on the feasibility of implant coating, so as to obtain better biologic fixation, and also as a carrier of osteoinductive substances, such as bone morphogenetic proteins and other growth factors (Keeting, et al. ${ }^{10}$, 1992; Price, et al. ${ }^{19}$, 1997; Hamadouche, Sedel ${ }^{5}$, 2000). Turunen, et al. ${ }^{24}, 1997$, also demonstrated the effectiveness of bioactive glass, as they improved the osseointegration of coated implants, provided better bone support, and presented increased stability when compared to machined implants.

Glass particles, when in contact with body fluids, trigger three reactions: diffusion, dissolution, and precipitation. Initially, an ionic exchange occurs between the particles and the solution, where sodium separates from glass and is replaced by protons from the environment. This way, the $\mathrm{pH}$ of the wound raises to neutral, creating good conditions for repair. Together with the diffusion reaction, there is dissolution of the glass silica weave, on which hydroxyl groups in oxygen and silica bonds are attacked, releasing silicic acid. When this acid is released, silanol groups form a hydrated layer on the glass surface. Through a polycondensation reaction, the silanol groups undergo regrouping, making up silica gel (Shapoff, et al. ${ }^{23}$, 1997). This layer will provide the main property of the material - bonding both to hard tissues and soft tissues (Yilmaz, et al. ${ }^{28}$, 1998). That bond occurs through bioactive fixation, involving collagen fibers inside the polycrystalline matrix on the implanted material surface induced by the carbonated apatite layer. The quick surface reaction of the material, and the formation of a calcium phosphate hydrated layer biologically active on its surface, are responsible for the fast bone formation. The gel layer, rich in silica, has a wide surface area, negatively charged, which works as a nucleation site to the formation of a calcium phosphate layer. This stage is initially amorphous, but it soon crystallizes to form an apatite hydroxycarbonate organized structure. This compound attracts collagen fibers, condroitin sulphate, and 
glycosaminoglycans, which are incorporated into that gel layer. Osteoblasts are also attracted to this layer; organic constituents are released, followed by mineralization.

Studying the rabbit femur, Oonish, et al. $.^{23}, 1996$, compared bioactive glass and synthetic hydroxyapatite (prepared by sintering at $1200^{\circ} \mathrm{C}$ in air, then crushed into granules and sieved to produce particles of 100 to 300 - $\mu$ m diameter), and demonstrated that the latter presented bone formation with little density around granules. There was greater bone formation around bioactive glass granules. After 12 weeks, particles could not be seen because they were completely incorporated into the newly formed bone tissue. Results from this study suggest that bioactive glass particles forming a cohesive layer over tissues easily remain inside the defect, even when the site is bleeding, and exceed by far hydroxyapatite inconveniences in retarding osteogenesis. This study is in agreement with the present findings, on which particles were interspersed with a new trabecular bone at 60 days, with mature lamellar aspect.

In this study, two different types of bioactive glass were evaluated: Biogran and Perioglas. Both materials are composed of silica, calcium, sodium and phosphorus, in the form of oxides. Biogran is a glass material with regular size particles, 300 to 350ìm, whereas Perioglas presents varying size particles, 90 to 710ìm. According to Yukna, et al. ${ }^{29}$, 2001, more regular particles (300 to 355ìm) are perfect for the treatment of periodontal bone defects. Zamet, et al..$^{30}$, 1997, in a clinical experiment, showed that varying size particles (90 to 710ìm) have a greater effect and a better gain in the clinical attachment level.

The present study showed bone formation on both types of granules. After 60 days, macroscopic verification of the implanted site was very difficult. There was no difference in bone formation around and inside fissures formed on particles from both groups. Both materials were bonded to adjacent bone tissue, preventing connective tissue migration; however, they were not osteoinductive. They acted as a filling material which, according to characteristics described previously, stimulated osteogenesis, with fissure or vesicle formation, behaved as an osteogenic nucleus, with osseointegrated particles, which were not completely reabsorbed and replaced in the time period investigated. The osteoprogenitor cells repopulating the graft came from the bone marrow, and from the endosteum and periosteum of the defect walls.

The osteogenic characteristic of bioactive glass particles may be related to the activation of an autocrine mechanism in osteoblasts, mediated by the induction of secretion of transforming growth factor-b, as occurs with the mitogenic effect of soluble silica on osteoblast-like cells in cultures (Cordioli, et al. ${ }^{4}$, 2001). Particles release a substantial concentration of soluble silica, as well as Ca and P, during the first few days in contact with fluids on the site, which may be responsible for the osteogenic effects observed in this study. These particles are then incorporated to the growing bone as a component, and are used to build new bone, yet the usefulness of these materials needs to be elucidated in further clinical studies.

\section{CONCLUSIONS}

Considering the results obtained, the following can be concluded:

- Both materials promoted comparable bone formation over the entire extension of the defect, independently of their granules size, thus confirming their biological osteoconductive property.

- No inflammatory reaction was observed due to the presence of the implanted materials.

- As a consequence of its osteoconductive and osseointegration properties, bioactive glass can be recommended for the treatment of bone defects, either separately or in combination with other techniques, or in composition with other bone substitute materials.

\section{REFERENCES}

1- Becker W, Becker BE, Caffesse RG. A comparison of demineralized freeze-dried bone and autologous bone to induce bone formation in human extraction sockets. J Periodontol 1994;65(12):1128-33.

2- Boyne, PJ. Osseous reconstruction of the maxilla and the mandible. Carol Stream: Quintessence; 1997.

3- Buser D, Dula K, Belser UC, Hirt HP, Berthold H. Localized ridge augmentation using guided bone regeneration. II. Surgical procedure in the mandible. Int J Periodontics Restorative Dent 1995; 15(1):11-29.

4- Cordioli G, Mazzocco C, Schepers E, Brugnolo E, Majzoub $Z$. Maxillary sinus floor augmentation using bioactive glass granules and autogenous bone with simultaneous implant placement. Clinical and histological findings. Clin Oral Implants Res 2001; 12(3):2708.

5- Hamadouche M, Sedel L. Ceramics in orthopaedics. J Bone Joint Surg (Br) 2000; 82-B (8):1095-9.

6- Hench LL, Paschal HA. Direct chemical bond of bioactive glassceramic materials to bone and muscle. J Biomed Mater Res 1973; 7:25-42.

7- Hench LL, Splinter RJ, Allen, WC. Bonding mechanisms at the interface of ceramic prosthetic materials. Part I. J Biomed Mater Res 1971; 2:117-41.

8- Jarcho M, Kay JF, Gumaer KI, Doremus RH, Drobeck HP.Tissue, cellular and subcellular events at a bone-ceramic hydroxylapatite interface.. J Bioeng 1977;1:79-92.

9- Jovanovic SA, Schenk RK, Orsini M, Kenney EB.Supracrestal bone formation around dental implants: an experimental dog study. Int J Oral Maxillofac Impl 1995; 10:23-31.

10- Keeting PE, Oursler MJ, Wiegand KE, Bonde SK, Spelsberg TC, Riggs BL. Zeolite A increases proliferation, differentiation, and transforming growth factor [beta] production in normal adult human osteoblast-like cells in vitro. J Bone Miner Res 1992; 7:12819. 
11- Kenney EB, Lekovic V, Han T, Carranza FA JR, Dimitrijevic B. The use of porous hydroxyapatite implant in periodontal defects. I. Clinical results after six months. J Periodontol 1985; 56:82-8.

12 - Low SB, King C, Krieger J. An evaluation of bioactive ceramic in the treatment of periodontal osseous defects. Int J Periodontics Restorative Dent 1997; 17:359-67.

13- Macedo N L, Lacaz Netto R, Jardini, MAN. Regeneração tecidual dirigida na reconstrução da atrofia localizada do rebordo alveolar. Rev Gaucha Odontol 1993; 41:365-7.

14- Mellonig JT. Porous particulate hydroxyapatite in a human periodontal osseous defect. A case report. Int J Periodontics Restorative Dent 1991; 11:217-23.

15- Moore WR, Graves SE, Brain GI. Synthetic bone graft substitutes. ANZ J. Surg 2001; 71(6):354-61.

16- Novaes Junior AB, Moraes N, Novaes AB. BioFill como membrana biológica no tratamento da lesão de furca com e sem a utilização de hidroxiapatita porosa. Rev Bras Odontol 1990; 47:2932 .

17- Oonishi H, Kushitani S, Yasukawa E, Iwaki H, Hench LL, Wilson J, et al. Particulate BioGlass compared with hydroxyapatite as a bone graft substitute. Clin Orthopaedics 1997; 334:316-25.

18- Park JS, Suh JJ, Choi SH, Moon IS, Cho KS, Kim CK, et al. Effects of pretreatment clinical parameters on bioactive glass implantation in intrabony periodontal defects. J Periodontol 2001; 72(6):730-40

19- Price N, Bendall SP, Frondoza C, Jinnah RH, Hungerford DS. Human osteoblast-like cells (MG63) proliferate on a bioglass surface. J Bone Joint Surg (Br) 1997; 79-B(3):349-400.

20- Salata LA, Craig GT, Brook IM. Bone healing following the use of hydroxyapatite or ionomeric bone substitutes alone or combined with a guided tissue regeneration technique. An animal study. Int J Oral Maxillofac Implants 1998; 13:44-51.

21- Schepers E, De Clercq M, Ducheyn P. Bioactive glass particulate material as a filler for bone lesions. J Oral Rehabil $1991 ; 18: 439-52$.

22- Seibert J, Nyman S. Localized ridge augmentation in dogs: a pilot study using membrane and hydroxyapatite. J Periodontol 1990; 61:157-65.

23- Shapoff CA, Alexander DC, Clark AE. Clinical use of a bioactive glass particulate in the treatment of human osseous defects. Compend Contin Educ Dent 1997;18:352-63.

24- Turunen T, Peltola J, Helenius H, Yli-Urpo A, Happonen RP. Bioactive glass and calcium carbonate granules as filler material around titanium and bioactive glass implants in the marrow space of the rabbit tibia. Clin Oral Impl Res 1997;8:96-102.

25- Vasconcelos LW, Lima EG, Takagui, RM. Enxerto ósseo autógeno em seio maxilar com implantes imediatos. Rev Assoc Paul Cir Dent 1998; 25:35-41.
26- Wilson J, Clark AE, Hall M. et al. Tissue response to BioGlass endosseous ridge maintenance implants. J Oral Implantol 1993; 19:295-302.

27- Wilson J, Low SB. Bioactive ceramics for periodontal treatment. Comparative studies in the Patus monkey. J Appl Biomater 1992; 3:123-9.

28- Yilmaz S, Efeoglu E, Kiliç AR. Alveolar reconstruction and/or preservation using root form bioglass cones. J Clin Periodontol 1998; 25(10):832-9.

29- Yukna RA, Evans GH, Aichelmann-Reidy MB, Mayer ET. Clinical comparison of bioactive glass bone replacement graft material and expanded polytetrafluorethylene barrier membrane in treating human mandibular molar class II furcations. J Periodontol 2001; 72(2):125-33.

30- Zamet JS, Darbar UR, Griffiths GS. et al. Particulate bioglass as a grafting material in the treatment of periodontal intrabony defects. J Clin Periodontol 1997; 24:410-8. 